\section{Entre a aldeia, a fazenda e a cidade: ocupação e uso do território entre os Guarani de Mato Grosso do Sul*}

\begin{abstract}
Amid the village, the farm and the city: territorial occupation and use amongst Guarani groups in Mato Grosso do Sul
\end{abstract}

(Brazil)

\author{
Alexandra Barbosa da Silva**
}

Resumo: Em Mato Grosso do Sul, a presença dos brancos fez com que os Guarani Kaiowa e Guarani Ñandéva assistissem à transformação de seu território, com o estabelecimento de fazendas e de cidades. Esses locais vieram a constituir espaços específicos, que não são menos ocupados e/ ou incorporados na vida cotidiana desses índios do que as ditas "aldeias" - espaços definidos como de uso exclusivo dos indígenas. Melhor dizendo, a ocupação e utilização desse território - ora diversificado em sua composição física e infraestrutural - não se apresenta ao observador de modo a priori como fragmentária e estanque em cada um destes espaços (ou seja, a "aldeia", a cidade e a fazenda); antes, observa-se que as atividades e relações aí desenvolvidas acabam por constituir um leque de possibilidades de obtenção de recursos materiais e imateriais para os grupos domésticos (isto é, o grupo familiar de três gerações), que são de fato o eixo fundamental de organização social destes indígenas.

Palavras-chave: Guarani Kaiowa e Nandéva; Território; Grupo doméstico.

Abstract: Due to the settling of the white man on farms and in cities, the Guarani Kaiowa and the Guarani Nandeva indigenous people experienced the progressive transformation of their ancestral territory. All these places have gradually converted into locales which are an integral part of indigenous life as much as the so called "villages" which are often considered to be the only space where the indigenous people circulate. 'Villages', 'cities' and 'farms' should not be seen as totally separate spaces since all of them are occupied and used by indigenous groups. The activities and relationships developed amid these urban and rural spaces allow the extended indigenous household to afford a wide range of material and immaterial resources.

Key-words: Guarani Kaiowa and Nandeva; Territory; Extended household.
* Uma primeira versão, mais resumida, deste texto foi apresentada no GT "Povos indígenas: dinâmica territorial e contextos urbanos", na 26ㅁ Reunião Brasileira de Antropologia (realizada entre os dias 1. e 4 de junho de 2008, em Porto Seguro, Bahia, Brasil) e publicada nos Anais do evento.

** Membro do Laboratório de Pesquisas em Etnicidade, Cultura e Desenvolvimento (LACED) / Museu Nacional / UFRJ. Doutora e Mestre em Antropologia pelo Programa de Pós-Graduação em Antropologia Social do Museu Nacional - UFRJ. alexandra.bar@terra.com.br.

Tellus, ano 9, n. 16, p. 81-104, jan./jun. 2009

Campo Grande - MS 


\section{Introdução}

No fim dos anos 1950, Cardoso de Oliveira analisava a situação dos Terena em Mato Grosso do Sul, elegendo como foco central de investigação a questão da identidade dos indivíduos situados sobretudo (mas não só) nos centros urbanos, fenômeno que ele analisou sob o prisma de um processo de integração à sociedade de classes. Tal ordem de coisas revela uma preocupação prática e teórica da época, ainda em muito, é de se observar, orientada pelo conceito de aculturação. Distinguindo-se dos que partilhavam uma visão de perda de identidade étnica gerada pelo que foi definido como "aculturação", o autor voltou-se para a produção da chamada "Escola de Manchester", com os estudos realizados na África, focando sobre os efeitos de deslocamento das pessoas de áreas rurais para o trabalho de extração nas minas, nas cidades. Daquele conjunto de trabalhos resultaram análises tornadas célebres - de autores como Max Gluckman, Clyde Mitchell, Philip Mayer -, sendo forjados conceitos como o de "tribalismo" e de "labour migration" - o primeiro, no sentido de construção de uma identidade, no local de chegada, com a manutenção de raízes tribais; o segundo, literalmente significando "migração para o trabalho" ${ }^{1}$. Justamente estes dois conceitos foram fundamentais para Cardoso de Oliveira construir sua argumentação, de que os Terena migrariam para as cidades, sem, contudo, perder suas raízes identitárias, ou seja, segundo ele, haveria um processo de urbanização, com a manutenção de uma identidade tribal. Em outras palavras, como ele próprio coloca, teria se dado uma integração sem assimilação (ver Cardoso de Oliveira, 1968 e 1976).

Mantendo isto em mente, minha experiência de pesquisa entre os Guarani (Kaiowa e Ñandéva) de Mato Grosso do Sul ${ }^{2}$ me conduz muito diretamente a traçar uma análise em diálogo com o autor, haja vista a proximidade tanto física quanto situacional entre os Terena e estes Guarani, nesse estado da federação. É importante ressaltar que os Guarani vivem em espaços territoriais bastante próximos aos dos Terena, e principalmente, para os intentos aqui, que ambos os grupos sofreram um processo de perda da terra muito similares. Tivemos, de fato, a criação, pelo órgão indigenista oficial, de espaços reservados para os índios, com uma concomitante liberação de terras para a colonização ${ }^{3}$. Especificamente com relação aos Guarani, o Serviço de Proteção aos Índios (SPI) criou, entre 1915 e 1928, oito áreas, a saber: Amambai, Dourados, Caarapó, Takuapiry, Limão Verde, Sassoró, Pirajuy e Porto Lindo. Já para os Terena, duas terras (Cachoeirinha e Taunay/Ipegue) foram "concedidas" pelo governo do estado, no início 
do século XX, sendo as demais (das quais dispõem hoje) "requeridas" pelo SPI, sempre ao estado, nos anos de 1920 e 1930 (neste sentido, ver, por exemplo, Azanha e Ladeira, 2004; Ferreira, 2007).

Lançando mão dos termos de Pacheco de Oliveira, temos que tanto os Guarani quanto os Terena passaram por um processo de territorialização (Pacheco de Oliveira, 2004), o qual foi promovido pelos mesmos agentes, ainda no então denominado estado de Mato Grosso. Para este autor, a territorialização é "uma intervenção da esfera política que associa (de forma prescritiva e insofismável) um território bem determinado a um conjunto de indivíduos e grupos sociais" (idem, p. 23).

Assim sendo, ao longo do tempo, tanto os Terena quanto os Kaiowa se viram constrangidos a saírem de suas terras, sendo encaminhados para as reservas oficiais. Ocorre, no entanto, que se tomamos em exame os dados de agentes do próprio SPI a respeito dos Kaiowa e Nandéva, percebemos que esses translados, antes que um fato consumado em um único momento, constituíram-se, efetivamente, em um processo. Um relatório de 1948, do funcionário Joaquim Fausto Prado (sob a rubrica de Estimativa da população indígena do sul de Mato Grosso, que vive fora dos Postos, em terras tidas como devolutas, em reservas sem instalações do SPI e em fazendas particulares) fornece um quadro geral da presença dos índios em seu território de ocupação histórica. Assim, tanto para a reserva de Sassoró quanto para a de Porto Lindo (ambas situadas no então distrito de Iguatemi) ele registrou 250 pessoas, enquanto que para a Vila Iguatemi em si, o número é de 1.500 pessoas (Prado, 1948); ou seja, apresentava-se uma enorme desproporção entre a população no interior e nos entornos destas reservas. Já no ano seguinte, Prado dizia que os índios do Posto Benjamin Constant (isto é, Amambai, a primeira reserva criada) viviam dispersos e que a maior parte trabalhava "em pequenos serviços na Cidade de Amambai e nas propriedades vizinhas do Posto, em serviços de lavoura" (Prado, 1949).

Estes quadros nos fornecem uma visão geral da situação em que se encontrava a territorialização naquele período: malgrado os esforços do SPI, a ocupação dava-se ainda de forma difusa, sobretudo no extremo sul - compreendendo as regiões de Amambai e Iguatemi. Além disso, no que concerne à região mais ao norte, em Fernandes Silva (1982, p. 22) encontramos a reprodução de parte de um ofício, datado de 1951, do diretor da Colônia Agrícola Nacional de Dourados (CAND) ${ }^{4}$, o engenheiro Tácito Pace. Ali, ele revelava que:

Embora possuindo o Posto Indígena Francisco Horta uma área ampla e esplêndida, destinada ao aldeamento dos índios Caiuas de Dourados, esses dificilmente se sujeitam ao aldeamento e em meados de 1950 tive notícias que estavam muitos deles retornando às matas do Panambi. 
O que ocorreu, efetivamente, é que muitas famílias permaneceram em (ou retornaram para) seus próprios lugares de origem, ora parcelados e titulados como propriedade privada: as fazendas. Nestes termos, tem-se claramente a percepção de uma incongruência de se falar em migração das pessoas para trabalhar em fazendas, muito embora seja justamente $o$ que faz Cardoso de Oliveira, com referência aos Terena. Tendo em conta estes indígenas, o autor se refere também a uma migração para as cidades. Assim sendo, os índios habitantes destes lugares são por ele denominados de "índios de fazenda" ou "de cidade". Sem me dedicar aos Terena, mas especificamente aos Guarani, desenvolverei a argumentação de que, dada a forma como historicamente os indivíduos e famílias guarani vêm se estabelecendo no espaço, não é apropriado se falar de "índio de cidade", ou "de fazenda", mas de índios na cidade ou na fazenda, ou ainda, como se pode claramente constatar hoje em dia, em beiras de rodovias, levando-se em conta necessariamente os sentidos que os próprios sujeitos atribuem para seus deslocamentos e estabelecimentos, nos contextos em que se encontram. Meu entendimento é que, em assim fazendo, poderemos encontrar meios conceptuais mais adequados para a interpretação dos dados, sendo isto bastante mais profícuo do que a alternativa de importação de conceitos e arcabouços teóricos de contextos outros para explicá-los. A orientação fundamental aqui é, através da análise, construir modelos de processos, segundo as sugestões de Fredrik Barth (1966 e 1987).

O presente artigo visa, portanto e em suma, estabelecer uma análise sobre a forma como se dão a ocupação e o uso do território pelos Guarani de Mato Grosso do Sul, constituindo-se de três tópicos. O primeiro é uma contextualização histórica sobre o território em pauta. Já o segundo se refere à percepção e à categorização do espaço, pelos indígenas, em um contexto de dominação colonial, sendo que, por fim, apresento uma reflexão que pretende demonstrar a relevância da comunidade política e do grupo doméstico e suas lógicas de orientação para as estratégias de ocupação e o uso do território de parte dos Kaiowa e Nandéva.

\section{O território: histórico e caracterização}

Conforme é vastamente ilustrado na bibliografia, o território de ocupação Guarani Kaiowa e Guarani Nandéva no Brasil é hoje representado por todo o cone sul do estado de Mato Grosso do Sul, adentrando pela fronteira com o Paraguai oriental. A exploração econômica desta 
região iniciou-se, de fato, a partir da segunda metade do século XIX com o fim da "Guerra da Tríplice Aliança" ou "Guerra do Paraguai", que definiu as fronteiras atuais -, através da extração da erva-mate nativa (característica de todo o território Guarani), desenvolvida pela Companhia Mate Larangeira. Esta atividade, contudo, não teve o intuito de colonização e portanto não afetou o uso que os índios faziam do território, constituindo eles a principal mão-de-obra na tarefa de corte e transporte. Apenas com o fim do monopólio então obtido pela Mate Larangeira, já na segunda década do século XX, foi que de fato houve uma ação governamental de estímulo à chegada de colonos brancos, com a titulação de terras (Brand, 1997; Thomaz de Almeida, 2001). Para a história local, é importante também, neste momento, a criação, em 1910, do "Serviço de Proteção aos Índios e Localização de Trabalhadores Nacionais" (SPILTN), o qual, alguns anos mais tarde (1917), teve sua função reduzida às três primeiras letras da sigla. Como já dito, entre 1915 e 1928, o SPI criou oito reservas no sul do então estado de Mato Grosso. A intenção aqui era dar solução à presença nativa, que se chocava com e era cada vez mais acuada por aquela dos novos proprietários de terras ${ }^{5}$. O fato é que chácaras (em menor medida) e fazendas foram-se sobrepondo neste território, os índios, dependendo do interesse do novo proprietário, ou eram conduzidos para as reservas ou permaneciam nas terras que sempre ocuparam, desta feita como mão-de-obra - bastante valiosa e fundamental para se constituirem as fazendas.

Se, por um lado, para o órgão indigenista, a condução das pessoas para as reservas deu-se de modo aleatório - resultando que famílias inimigas entre si passassem a ter que conviver nesses espaços delimitados -, por outro, as próprias famílias seguiam uma lógica bem definida de ocupação do território. Tal lógica se fundamentava na ocupação de cabeceiras e ao longo de cursos d'água. Se nos remetemos aos inícios do século XVII, com os dados do jesuíta Montoya, vemos tal característica de ocupação e somos informados ainda que era guardada a distância de "uma, duas, três ou mais léguas" entre um e outro agrupamento de pessoas (Montoya, 1985, p. 34).

Nos relatos colhidos atualmente sobre os períodos anteriores à expulsão de suas terras de origem, as pessoas reafirmam a expectativa de realização desta forma de assentamento, e podemos perceber que os nomes de rios e córregos ocupados passavam a servir de topônimos. Neste modo, cada família extensa habitava o que era definido como um tendápe ("lugar"), nomeado a partir dos córregos e rios (ver Barbosa da Silva, 2007).

Considerando-se que os Guarani são conhecidos historicamente como povos de economia baseada fundamentalmente na agricultura, 
com a realização de caça, pesca e coleta como atividades complementares, tem-se em mente que os espaços para realização destas últimas atividades era de uso compartilhado por famílias, em um determinado raio, conformando espaços territoriais específicos - como se verá mais abaixo. $\mathrm{O}$ resultado disto é uma morfologia social ${ }^{6}$ baseada na dispersão. Justamente o contrário disto, isto é, a nucleação, é que gera a idéia de "aldeia", totalmente impertinente para o caso dos Guarani. Não obstante, foi este último o modelo que orientou a atuação dos funcionários do então SPI. Com o correr do tempo, o termo "aldeia" ganhou uso generalizado mesmo entre os próprios indígenas.

Os registros históricos indicam que, no passado, cada grupo macrofamiliar guarani, encabeçado pelo tamõi ("avô") e a jari ("avó"), vivia sob um único teto, em uma grande casa (oygusu ou ogajekutu) ${ }^{7}$. Com o passar do tempo, este padrão foi mudando, cada família nuclear habitando separadamente, mas sempre se situando nas proximidades da casa do tamõi/ jari, constituindo-se uma unidade basilar de três gerações, um padrão que é possível se constatar mesmo hoje em dia nas Terras Indígenas ${ }^{8}$. Nesses termos, os mais idosos continuaram a ser o eixo articulador das decisões do grupo familiar, de modo que a lógica de reciprocidade e das obrigações no seio do grupo se manteve (neste sentido, cf. Benites, 2003 e 2009).

\section{A percepção e a categorização do espaço em um contexto de dominação colonial}

Importa observar que, para as pessoas, a categorização do espaço é sempre um processo dinâmico e relacional. Antes da presença dos colonos, os índios não se deparavam com a necessidade de estabelecer delimitações bastante precisas da terra - como veio a ocorrer. A dinâmica conhecida era a das guerras com os demais grupos nativos, entre os quais os Mbayá-Guaicuru eram fortes adversários. Susnik (1982) relata que, em meados do século XIX, também os Terena e outros grupos ChanéGuaná procedentes do oeste faziam incursões, à procura de cativos guarani. Assim, como bem observa Mura (2006), a categoria de tekoha, (onde teko é "jeito, modo de ser", e ha, um sufixo que indica lugar) ${ }^{9}$ passou a ser amplamente verbalizada nos anos 1970, no Paraguai, a partir da necessidade dos grupos Guarani garantirem espaços territoriais, dado o avanço da ocupação não-indígena. Muito embora as condições e o processo tenham tido suas particularidades, a situação fundiária enfrentada pelos índios no Brasil e no Paraguai era muito símile. Foi assim que se 
assistiu, no lado brasileiro, ao deslanchar de um persistente movimento de reivindicação das terras perdidas - do qual resultaram 20 novas áreas identificadas pela FUNAI até o momento.

Resultado, portanto, de processos dinâmicos de relação com nãoíndios, para os Guarani a categoria tekoha indica fundamentalmente a ligação com a terra, não estando em causa uma cristalização do entendimento, com definição de limites bem precisos ${ }^{10}$. Além disso, é de se ter em conta que a referência mais imediata das pessoas hoje quando se referem ao passado é feita ao tendápe (como vimos, "lugar"). Em sendo esta a referência dos membros de uma família extensa, as relações eram vistas como se dando com membros de outra família, em um outro tendápe. Como se vê, a definição do tekoha reside fundamentalmente no fato de que ele é resultado de relações entre famílias extensas (isto é, as relações comunitárias), sendo o limite espacial dado pelo alcance das relações estabelecidas. Assim sendo, o tekoha é o espaço territorial onde são estabelecidas relações de caráter comunitário e a partir do que se constituirão laços intercomunitários, numa região mais ampliada - que é denominada tekoha guasu (guasu significando "grande", "amplo").

Um elemento bastante significativo para a apreensão do desenvolvimento das relações no espaço do tekoha guasu é a realização de rituais, que requer toda uma mobilização, tanto da parte daqueles que os conduzirão quanto dos demais participantes. A concentração de pessoas típica desses eventos demanda deslocamentos, os relatos feitos hoje neste sentido enfatizanm que se demoravam muitos dias caminhando para chegar ao local do evento. O percurso em si era algo extremamente significativo, visto que se parava para caçar, pescar e coletar frutas, plantas medicinais, mel etc., nas extensões de mato que outrora caracterizavam a região. Durante já os dias de festejos, a presença e o largo consumo da chich ${ }^{11}$ é narrada com ênfase e entusiasmo, as pessoas revelando que se constituía, de fato, um circuito de festas, cujo anfitrião se revezava: ao findar a festa (guachire) em uma casa, outra iniciava-se em uma segunda, e assim por diante. Em Guarani, a referência a este fenômeno é (ko)arasa - que tem o significado de continuidade, sequência.

\section{Mudanças e adaptações}

Fato importante de ser destacado é que, mesmo com a constituição das fazendas, tais práticas não deixaram de ser realizadas, cada família que organizava os festejos e rituais fazia (como ainda faz) convites em 
um raio amplo num tekoha guasu, cuja resposta funcionava (e funciona) obviamente a partir de uma rede de relações constituída. Nesses termos, observa-se que, embora o padrão de distribuição dos grupos em questão tenha encontrado fortes constrangimentos de espaço - tanto pela própria constituição das reservas quanto pelo inchaço progressivo destas -, não se pode dizer que as pessoas deixaram de manter uma mobilidade, a de realizar rituais e de usar o território. O que se tem de novo a partir de um contexto de relações com os brancos que é pautado pela dominação, é a incorporação dos novos "ambientes" que são as fazendas e os núcleos urbanos, nas estratégias de obtenção de recursos. Este termo, ambiente, entendo-o em um sentido socioecológico, compreendendo uma infraestrutura material (as instalações físicas: construções, caminhos, cercas, árvores, pastagens, ruas, praças etc.) específica, pondo à disposição dos sujeitos determinados recursos e permitindo o desenvolvimento de determinadas atividades, as quais, embora características, podem não ser exclusivas. Assim, o ambiente é um espaço físico de relações, unidade constituinte de um território. (cf. Barbosa da Silva, 2007).

Uma constatação fundamental é que a capilaridade da presença de membros de uma família extensa nos ambientes diversos (como o são as fazendas estabelecidas, as cidades construídas, e mesmo as beiras de rodovias), em muitos casos tem por efeito justamente facilitar o acesso e a obtenção de recursos.

É de se ter em mente que antes as pessoas se deparavam com um ambiente constituído exclusivamente por matas e cerrados. Ao serem suas atividades (incluindo seus deslocamentos) em grande parte orientadas à busca por recursos, eram elas desenvolvidas a partir das relações estabelecidas entre indivíduos, de grupos familiares e/ou etnicamente diferentes, ou seja, envolvendo estratégias e negociações em forma de alianças ou de conflitos. Para sermos mais precisos, visto que, para os Guarani, tudo no Universo, cada ser e objeto, tem seu dono (o jára, que pode ser traduzido como "espírito-dono" ou "espírito guardião"), também era (e é) necessário manter relações com estas entidades, os jára, apelando-lhes, através de oração (ñembo'e), para a consecução do recurso/benefício almejado - como exemplo, o pedido feito ao dono da caça (so'o jára) da cessão de um animal, que, então, seria obtido como presa em uma caçada. Em outras palavras, o uso e apropriação do território se constituíam (como se constituem hoje) através de relações sociopolíticas, envolvendo avaliações das condições e dos sujeitos com quem se interage, numa percepção ampla destes sujeitos, como seres de um único Cosmo (cf. Mura, 2006). Neste sentido, a transformação do ambiente, com a cons- 
tituição de fazendas e de núcleos urbanos, acarretou o aparecimento de novas paisagens e de novos recursos, além da necessidade de convivência mais sistemática com os brancos, eles próprios, outros jára, ou seja, donos das coisas que pertencem aos e/ou que são de origem dos brancos.

Em um primeiro momento, como indicado, a atividade ervateira era apenas de extrativismo, e não com o intento de colonização, a mão-de-obra utilizada era maciçamente de índios guarani, e, apenas de modo muito escasso, de brancos (mormente de nacionalidade paraguaia - cf. Pimentel Barboza, 1927). Assim, ela suscitou entre os índios uma forma específica de deslocamento no território, com o estabelecimento de construções temporárias em meio aos ervais, os chamados "ranchos", no apoio ao trabalho de corte da planta. A saída de famílias nucleares da antiga habitação grande e única teve um grande incremento naquele então, os grupos macrofamiliares passando a ter seus membros presentes de modo mais difuso no território. Com a colonização, isto é, a chegada em peso dos brancos, o que se apresentou como diferente à percepção e experiência dos indígenas é a nova modalidade de apropriação do território, com o estabelecimento de limites físicos e a consequente perda da exclusividade de ocupação. No entanto, os novos ambientes criados, seus recursos e seus jára (donos) passaram, também, eles, a fazer parte do universo de relações dos índios, sendo adaptados a uma lógica orientadora. É de se depreender, por outro lado, que a partir das especificidades que lhes são subjacentes, estes novos elementos vieram a gerar adaptações nesta mesma lógica, visto que em um dinamismo processual, não é de se supor que algum elemento cultural possa se cristalizar de uma vez por todas, senão servir de parâmetros para contínuas adaptações, ele próprio se adaptando.

\section{A centralidade da comunidade política e do grupo doméstico nas estratégias de ocupação e de uso do território}

Para melhor entendimento dos fatores a serem levados em consideração nesta análise, devemos abrir espaço para considerar alguns aspectos. O primeiro deles é a configuração das famílias extensas guarani enquanto comunidades políticas e grupos domésticos, em Mato Grosso do Sul; o segundo é a consideração mais ampla dos significados das transformações efetivadas fisicamente no território em questão.

No que tange ao primeiro ponto, é preciso se ter em mente a centralidade que as relações de parentesco têm para os Guarani, como para os povos indígenas em geral. Tendo-se isto em mente, gostaria de 
destacar que, no que diz respeito ao estabelecimento das relações sociais, nos deparamos com uma distinção, sobre a qual alguns autores chamaram a atenção, entre, por um lado, a adscrição e, por outro, a escolha dos sujeitos. Em um artigo de 1978, Barth se apega a esta distinção - ressaltando que o segundo caso, i.e. o da escolha, se dá "tendo-se algum objetivo particular e limitado em mente" (op.cit., p. 182) -, afirmando muito brevemente que cada uma dessas categorias está relacionada a "sociedades não ocidentais" e "ocidentais", respectivamente ${ }^{12}$. Já nos remetendo a Barnes, encontramos o autor fundamentando-se sobre a diferenciação entre sociedades de pequena e de grande escala, a partir da possibilidade de relacionar-se com mais ou menos pessoas, podendo-se entrar em contato com desconhecidos. Deste modo, argumenta ele que uma análise em termos de rede social é plausível nas "comunidades urbanas populosas" (segundo sua definição), visto que, "no meio social de cada pessoa, existem muitos desconhecidos, com os quais não se possui nenhuma interação significativa" - e completa: "Isto não acontece em sociedades de pequena escala" (Barnes, 1987, p.187). Denominando estas últimas como "sociedades tribais", o autor afirma que nestas não haveria espaço para relações idiossincráticas de amizade com estranhos. Ora, à parte a crítica absolutamente pertinente de que nada indica que "nas sociedades de grande escala" (se optamos por este termo) as coisas se passem como ele descreve, a ênfase de Barnes neste artigo parte, de fato e propositalmente, de uma diferenciação um tanto esquemática e reducionista, concebendo unidades sociais ideais polarizadas - não obstante uma breve reserva sua de que "entre os dois extremos haveria muitos tipos intermediários". As ditas "sociedades de pequena escala" são tomadas por ele como unidades fechadas em si, autosuficientes. Para além disso, embora a intenção intrínseca seja possibilitar um mapeamento das redes de relações das pessoas, isto não leva necessariamente a uma visão dinâmica da parte do autor, antes o contrário, incorrendo ele em um formalismo, prendendose à concepção de que, "nas sociedades tribais", não haveria outra coisa senão papéis/posições formais de cada indivíduo em uma rede. É o que transparece da seguinte afirmação sua: "Na sociedade tribal, o padrão de relacionamentos na rede total revela a sua estrutura institucional, já que nem todas as relações são do mesmo tipo" (ibid., p. 187).

No entanto, há uma brecha neste esquema do autor, em uma ressalva que ele põe nos seguintes termos: mesmo numa situação tribal-limite, em que "todo mundo conhece todo mundo", mesmo aí "os originadores de ação deveriam ser seletivos, posto que não poderiam mobilizar toda a sociedade todas as vezes que precisassem obter algo" (ibid., p. 188). 
Para os dados com os quais lido aqui, é evidente que esta diferenciação tornada em dicotomia não é absolutamente útil. Mais profícuo é se pensar que, de fato, estão em questão princípios orientadores diferentes, não necessariamente característicos de um tipo de sociedade. Dependendo da situação dada, a adscrição e a escolha podem se combinar, de formas diferentes. Em se considerando os indígenas em causa, temos que ambas as lógicas de organização das relações se fazem presentes, com a particularidade de que as ações são direcionadas diferentemente para atores diferentes. No caso das relações entre os indivíduos que compõem um grupo doméstico, está em questão a necessidade de adequação de cada sujeito a esta particular configuração social, com a adscrição tendo um papel importante, tanto internamente ao grupo, quanto externamente, para se definirem alianças políticas, através de casamentos.

De fato, e mais especificamente, pode-se afirmar que o que se observa hoje em dia, em Mato Grosso do Sul, é uma relação continuada e intensa entre membros de um mesmo grupo, constituído este a partir de relações consanguíneas e afins: a comunidade política. Devo observar que utilizo este termo considerando o sentido empregado por Weber, de construção (portanto, a partir de um processo) da comunização (cf. Weber, 1983). Nesses termos, a comunidade pode mudar sua configuração no tempo, a partir de dissensos e cisões, configurando-se novos arranjos ${ }^{13}$.

Tendo isto em mente, é importante agora salientar que para estes indígenas há uma unidade que reveste uma relevância fundamental. Trata-se do grupo doméstico, ou seja, um grupo familiar de três gerações (abrangendo os cônjuges incorporados através do casamento). Em guarani, este grupo é denominado te'yi ou ñemoñare, constituindo-se ao mesmo tempo um grupo de produção e consumo, em que cada um dos seus integrantes tem definida uma série de obrigações recíprocas. O respeito a essas obrigações é fundamental para a manutenção do grupo no tempo, sendo as experiências e aprendizados dos sujeitos sempre atualizados em seu seio, nas situações cotidianas. Barth, dedicando-se a uma reflexão sobre a estrutura da ação social, postula o seguinte, por meio de uma diferenciação das noções de evento e ato:

O primeiro refere-se ao aspecto externo do comportamento, aos dados objetivos e mensuráveis do positivismo. O segundo, ao significado intencional e interpretado do comportamento, o seu significado para pessoas conscientes, com conjuntos específicos de crenças e deexperiências. Um evento é um ato em virtude de ser intencional e interpretável.

[...] O precipitado (no sentido químico da palavra) da interpretação dos atos na pessoa é a sua experiência e, sinteticamente, em um plano 
mais distanciado, seus conhecimentos e valores, que por sua vez podem retroagir sobre planos e objetivos futuros, bem como sobre futuras interpretações de atos (2000b, p. 173-174).

Aderindo a esta orientação do autor, podemos entender que as pessoas seguem determinadas lógicas culturalmente moldadas, mas isto não quer dizer que estas lógicas não sejam continuamente atualizadas, a partir das situações cotidianas efetivas que se apresentam aos sujeitos, envolvendo tanto os membros de seu grupo doméstico quanto os brancos. $\mathrm{O}$ processo que parece se desenvolver é que as decisões são tomadas a partir de determinados valores culturais, sendo que cada família pode dar respostas diferentes para situações específicas a partir dos seus interesses, também específicos. No entanto, ao fim e ao cabo, temos por corolário que as estratégias e tomadas de decisão dos sujeitos estão firmemente orientadas pelas necessidades que se geram a partir das interações no seio de seu grupo doméstico. A busca de prestígio por um indivíduo ganha pleno sentido quando seus efeitos e seu reconhecimento se dão no interior de seu grupo; de outro modo, o grupo o exilaria, não o reconhecendo mais como membro. Daí provém a força da lógica de obrigações recíprocas.

De um modo geral, as interações no interior do grupo doméstico têm sido enfocadas nos estudos antropológicos, fundamentalmente a partir do aspecto econômico, tomando-se por base a produção e o consumo de bens e produtos, e sua distribuição no interior dessa unidade social. Obviamente, dada essa centralidade que assume o te'yi/ñemoñare, aspectos outros para além do econômico (como, por exemplo, o da educação das crianças e o da transmissão de conhecimentos, valores, crenças etc.) devem ser também levados em conta em uma análise que se pretenda mais complexa ${ }^{14}$.

As formulações de dois autores são relevantes para nos permitir analisar as dinâmicas desenvolvidas no seio dos grupos domésticos guarani nos dias de hoje. Wilk e Netting (1984) propuseram uma definição das households a partir das atividades de produção e distribuição, mais do que a partir de um critério de corresidência. Para os autores, um grupo doméstico que vive sob um único teto, denominado dwelling unit (unidade habitacional), não forma propriamente uma unidade doméstica (household) em todos os casos. Uma unidade doméstica composta por uma única unidade habitacional será definida unidade doméstica independente (independet household), enquanto um aglomerado de unidades habitacionais sob única direção formaria uma household cluster. Por seu turno, esta unidade doméstica agregada, observa precisamente Wilk, pode ser de dois tipos, isto é, tight (restrita) e loose (flexível) (Wilk, 1984, p. 224-227). No primeiro caso, as atividades realizadas pelos integrantes da unidade 
doméstica estariam vinculadas mais que tudo a um trabalho coletivo, sendo que, no segundo caso, embora mantendo como objetivo beneficiar a família extensa como um todo, as atividades podem ser muito diversificadas e desenvolvidas de modo autônomo por cada unidade habitacional.

Tendo isto em mente, pode-se dizer que essa noção de unidade doméstica agregada flexível é bastante útil para abordarmos em sua generalidade os grupos domésticos kaiowa e ñandéva nos dias de hoje, não só nas chamadas aldeias, mas nos demais ambientes referidos. A apresentação de exemplos empíricos permitirá um melhor entendimento desta afirmação.

\section{Três casos emblemáticos}

Delineados de forma breve, consideremos três casos - retirados dentre outros, de um trabalho meu anterior (Barbosa da Silva, 2007). O primeiro deles é o de Pedro Moreli, que reside na cidade de Tacuru (com 9.600 hab. em julho de 2005 - fonte: IBGE), onde o encontrei, em 2004, com a esposa e quatro filhos, sendo um destes a filha mais velha (então com 15 anos), juntamente com seu jovem marido. Em um lote de medida padrão da cidade ( $12 \mathrm{~m} \times 30 \mathrm{~m}$ ), encontra-se a casa de Pedro, constituída por três construções, uma delas sendo a cozinha, e outra, menor, o banheiro. Em 2004, este conjunto ganharia ainda um outro cômodo, para onde se deslocou a filha recém-casada ${ }^{15}$. Tacuru é um município que, como todos em Mato Grosso do Sul, tem seu núcleo urbano rodeado por fazendas (de fato, antigos tekoha). Comporta ainda duas terras indígenas: Sassoró (uma das oito reservas instituídas pelo SPI) e Jaguapire. É evidente que outrora todo este espaço territorial constituía um tekoha guasu, ocupado de modo exclusivo pelas famílias guarani daí originárias. Pedro e sua esposa nasceram na reserva de Sassoró, onde ainda se encontram as respectivas famílias de origem. Os filhos pequenos do atual casamento de seu pai visitam Pedro frequentemente, que envia para o pai algum mantimento, mormente carne. Por outro lado, a casa de Pedro também é frequentada por seus irmãos e pelos irmãos de sua esposa, bem como por seus primos, vivendo estes na T.I. Jaguapire, todos estes ali pousando em determinados períodos, quando realizam trabalhos pontuais, a changa, nas fazendas de Tacuru, ou quando necessitam de atendimento médico na cidade, por exemplo. O próprio pai de Pedro, quando se separou, mudou-se para a casa do filho, depois retornando para a reserva, onde voltou a se casar. Por seu turno, o sustento econômico do núcleo familiar de Pedro (que em 2007 se tornaria avô) provém de seu trabalho nas fazendas nos arredores de sua casa, em Tacuru e municípios vizinhos, bem 
como de idas para o corte de cana em usinas de álcool de outras cidades, em Mato Grosso do Sul, além das bolsas referentes à freqeentação das filhas menores à escola - em Tacuru. Uma justificativa utilizada por Pedro é que estar ali lhe permite um acesso mais fácil a uma renda regular, coisa que não ocorria na reserva.

Visto isto, é patente o fato de que estar em Tacuru lhe outorga uma condição privilegiada com relação à que ele poderia alcançar na aldeia. Esta condição lhe permite uma obtenção de prestígio (o qual pode ser entendido como um recurso imaterial, que se inclui entre as buscas dos sujeitos) em face de seus parentes. Como é perceptível, a constante frequentação destes últimos é um elemento central para Pedro; recusá-las significaria um afastamento de seu grupo de origem (a comunidade política à qual pertence), o que ele não faz, assim se mantendo plenamente reconhecido dentro dele, em uma posição tanto mais prestigiosa quanto mais ele tem a possibilidade de atender às demandas que lhe são feitas.

O segundo exemplo a que remeto agora é o de Arlindo Ormedo, que, em fins de 2004, vivia em um lote de terra à beira da rodovia, em Iguatemi (município contíguo à Tacuru). Seu abrigo era uma minúscula construção, feita de galhos de árvore e o plástico preto chamado comumente de lona. Com ele, estavam a esposa e dois filhos bem pequenos. Outras duas filhas suas viviam na referida reserva de Sassoró, com os respectivos esposos.

Estando ali havia quatro meses, até não muito tempo antes, Arlindo tinha sido o "capitão" ${ }^{16}$ da reserva de Sassoró; no entanto, uma contenda lhe resultou na perda do posto. Em grande medida por decorrência deste fato, Arlindo saiu da reserva, transferindo-se não para a cidade de Tacuru, mas para a vizinha Iguatemi (15.000 hab. em julho de 2005 - fonte: IBGE), ciente de que lá havia a possibilidade de encontrar trabalho em um frigorífico - o que de fato ocorreu. Para instalar-se, tinha conhecimento da existência de diversos barracos e casas construídas de modo bastante precário exatamente defronte do frigorífico. Nesse local havia uma previsão de loteamento oficial pelo prefeito, onde seriam construídas casas populares. Ocorre que Arlindo já trabalhara para o prefeito, em sua chácara, de modo que o conhecia. Foi com ele que Arlindo obteve a permissão para instalarse no local. A intenção manifestada por Arlindo era a de, decorrido mais ou menos um mês, transferir-se para a T.I. Cerrito (situada no município de Eldorado, contíguo a Iguatemi), onde vivia um tio seu. Disse ele ter ido conversar com este tio e que estava acertando ir juntar-se a ele.

Por fim, é interessante considerar o exemplo de Aníbal Riquelme. Aníbal, de 67 anos, aposentado, é originário do tekoha Pyelito Kue, nas 
proximidades da reserva de Sassoró. Em outubro de 2004, ele estava no terreno do depósito de lixo da cidade de Iguatemi (o "lixão") ${ }^{17}$ juntamente com parte de sua família extensa, isto é, a esposa (também aposentada), uma filha de 12 anos e outra filha, com o marido e três filhos. A explicação dada por Aníbal para ali estar é que o espaço onde se encontra o "lixão" "é da prefeitura e qualquer um pode morar." Importa observar que uma terceira filha de Aníbal (também casada e atualmente vivendo em uma fazenda em Iguatemi) já havia morado nesse lugar por um período, porque, segundo a família, "ali é o lugar mais perto pra morar". Obviamente que tinham em vista se tratar de um lugar situado em um determinado raio de abrangência do tekoha de origem de Aníbal e livre de controles para o seu acesso. Embora vivendo em uma fazenda, esta última filha ia sempre visitar os pais. Naquele local, Aníbal cercara um espaço de cerca de 1,5 hectares, fazendo uma casa de galhos de árvore, um pouco de madeira e lona preta. Na contiguidade da casa, havia um pequeno espaço, onde fora plantada mandioca. Para obtenção de água, Aníbal se dirigia a uma mina, distante uns 300 metros da casa. Sua principal argumentação para não se estabelecer na reserva de Sassoró - vista sua proximidade com seu tekoha de origem - era que na reserva havia gente demais, ocorrendo muitas brigas, todos estando sujeitos ao jugo do "capitão", enquanto ali ele podia estar em paz.

Ora, estes três exemplos incluem-se em uma gama bem maior de outros encontráveis hoje em Mato Grosso do Sul. Assim concentremonos sobre os dados que eles nos fornecem.

No que concerne a Aníbal, vê-se que, juntamente com sua esposa, ele atua como o líder de seu grupo doméstico. $\mathrm{O}$ fato de ambos serem aposentados reforça mais esta posição, em termos econômicos, servindo eles de referência e apoio para os demais membros. É de se imaginar que o genro, apto a trabalhar, em algum momento se deslocaria para algum serviço, mas a relação de sua esposa (e, consequentemente, dele próprio) com o casal mais idoso se mantém como relevante, tanto em termos afetivos como econômicos. Assim como a terceira das filhas de Aníbal mantém visitas aos pais, nada impede que, caso seja necessário, ela se transfira para junto deles - seja no "lixão" ou em qualquer outro lugar onde venham a estar.

Com relação ao caso de Pedro Moreli, é de se observar que, em 2004, uma vez que sua filha contraiu matrimônio, ele se tornou o potencial líder de uma família de três gerações, condição esta que suplanta aquela de filho, com relação a seu próprio pai - à qual, de fato, sempre se manteve fiel, sustentando as correspondentes obrigações, como foi 
possível ver. De fato, já avô, ele, em vez de seu pai, passou a ser o eixo articulador das tomadas de decisão deste novo grupo doméstico, a relação genro-sogro tornando-se extremamente relevante neste momento. Em termos dos efeitos desta dinâmica, um fator extremamente significativo é que, dada sua nova condição, seu prestígio social aumentou em muito perante os demais parentes da reserva de Sassoró que o tinham como ponto de referência e apoio, ali em Tacuru.

Finalmente, considerando o caso de Arlindo, as condições que construíra para estar onde estava em fins de 2004 não eram em nada determinantes e imprescindíveis para ele, incluindo aí o emprego no frigorífico - como se poderia pensar à primeira vista. Dada a impossibilidade de tornar à reserva de Sassoró, a situação que construíra constituiu, de fato, uma forma de possibilitar novos arranjos na direção de um estabelecimento que lhe era preferível. É de se observar aqui o detalhe de busca de aproximação com um tio. Para os Guarani, a relação tiosobrinho é socialmente relevante - sobretudo aquela entre irmão da mãefilho da irmã ${ }^{18}$.

O recurso analítico a estes casos nos permite a imediata percepção de uma fluida circulação por um amplo espaço territorial, com o aproveitamento pleno dos recursos nele disponíveis - seja para morar, bem como para plantar e para trabalhar em troca de remuneração, por exemplo. Através deles alcançamos uma aproximação ao entendimento dos sujeitos sobre o território onde vivem, sendo este de ocupação histórica, fator que constitui um elemento central para suas tomadas de decisão, não como mônadas isoladas, mas como membros de um tipo organizacional (Barth, 2000) ${ }^{19}$ para eles fundamental: a família extensa como grupo doméstico. Tornarei a esta questão mais adiante, nas reflexões conclusivas.

\section{Ainda mudanças e adaptações}

Concentrando-me agora no segundo dos pontos indicados páginas antes, volto-me a um esforço para analisar os efeitos das transformações físicas no território sobre a morfologia social e a tomada de decisão dos sujeitos. É de se observar que foi colocada à disposição destes toda uma gama de novos recursos, os quais foram incorporados, em um processo adaptativo. Tomemos inicialmente em consideração um esquema, que é o seguinte: 

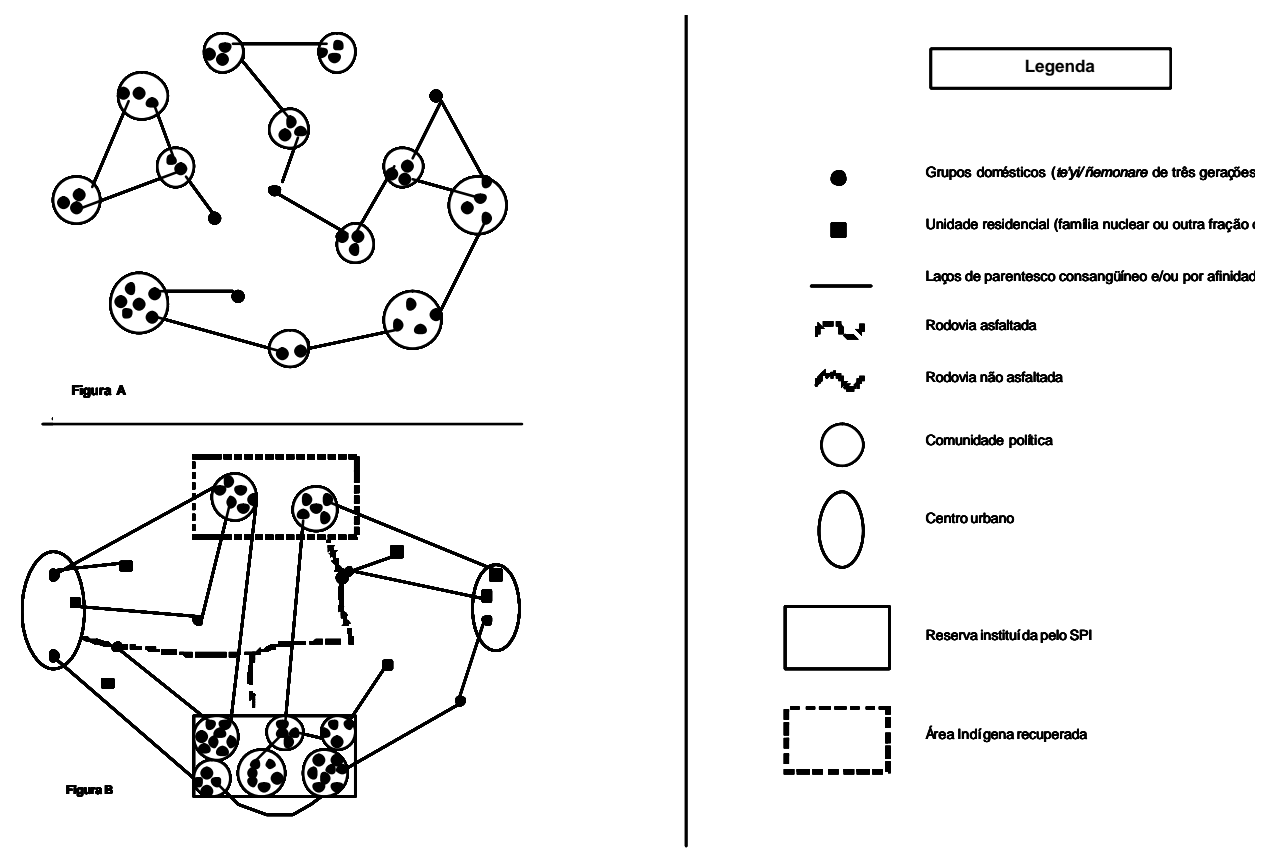

Esquema

Este esquema busca representar em termos gráficos a dinâmica que aqui se está analisando. Assim, a figura A retrata uma morfologia com grande dispersão pelo território, com as famílias extensas constituindo comunidades políticas locais; os círculos, por seu turno, ressaltam situações de associação entre várias destas famílias. Assim, na ausência de barreiras restritivas no espaço - a não ser aquelas que o jogo de forças estabelece para a conformação de espaços específicos de jurisdição -, as famílias têm possibilidades de estabelecer relações praticamente em todas as direções. Para este estabelecimento, a proximidade física é um fator não exatamente determinante, mas antes facilitador.

De antemão, a visualidade que esta figura permite deixa patente $o$ fato de que não é possível se definir uma centralidade, um foco central ordenador; se há um eixo, este é constituído pelas próprias famílias extensas, as quais interagem entre si - obviamente através de seus membros.

Dito isto, se deslocamos o foco agora para a figura B, temos um assentamento no espaço bastante diverso da situação anterior. Nesta nova distribuição, é de se ressaltar, de início, a existência de famílias nucleares destacadas, podendo estar em uma fazenda ou cidade, ou ainda à beira de uma rodovia, mas é de se observar, de qualquer modo, que elas estão interligadas às demais, que conformam uma mesma família extensa, bem 
como a outras destas unidades (te'yi/ñemoñare). Outra importantíssima observação que daí ressalta é que os processos de territorialização e colonização criaram constrangimentos, mas não alteraram a forma de as famílias se organizarem política e socialmente a partir de espaços mais amplos do que as reservas, constituindo-se redes de relações que não são restringidas ou definidas pelos locais diversos onde as pessoas estão situadas. Não é possível, nesses termos, afirmar que se efetivou uma transformação de uma morfologia social em uma outra. Isto porque não há nenhuma determinação que faça com que, em havendo a possibilidade contrária, as famílias se mantenham restritas aos espaços que lhes têm sido possível ocupar - com isto apresentando-se uma densidade demográfica bastante diversa daquela retratada na figura A. Nesses termos, revela-se mais fortemente o fato de que a aldeia se constitui em uma constrição, historicamente construída, nesses processos sociais. Em outras palavras, a situação retratada na figura B é decorrente da falta de liberdade para as famílias se assentarem como outrora. Contudo, não obstante esta situação de constrição, há casos que expressam justamente uma busca por recuperação de condições de vida mais favoráveis, fora das aldeias. É preciso ressaltar aqui que não está em questionamento o fato de que a situação almejada é a ocupação exclusiva do território, em termos étnicos - o que em princípio caracteriza a aldeia (isto é, as reservas antigas e as áreas recuperadas a partir das reivindicações). O que ocorre é que as aldeias hoje apresentam condições extremamente negativas - seja em termos socioeconômicos, seja em termos emocionais-afetivos etc. - para as pessoas poderem desenvolver suas atividades cotidianas. O pouco espaço hoje em posse dos indivíduos acarreta más possibilidades para fazer a terra produzir. Além disso, tem-se uma superpopulação, a qual, por sua vez, potencializa os conflitos entre famílias inimigas entre si - que, como dito, se vêem constritas a conviverem nesses espaços restritos.

\section{Reflexões conclusivas}

Tendo-se em mente tudo o que foi dito, diante de nós se apresenta uma complexidade que pouco ou nada pode ser entendida através de noções como a de tribalismo ou de labour migration, conforme eu já indicava aqui no início. No caso em pauta, dos Guarani, é patente o fato de que não se pode falar propriamente de "migração" - tendo-se este fenômeno como o ato de deixar um lugar considerado como próprio, ao qual se está ligado por um sentido de pertencimento, conhecido, de relações primárias, indo-se então para um lugar alhures, desconhecido, ao qual, de 
início, não se pertence ${ }^{20}$-, sobretudo quando muitas vezes as pessoas sequer saem do lugar onde nasceram, muito embora tornado fazenda.

Neste sentido, vê-se que mais que "migração", ocorre, de fato, uma circulação pelos vários ambientes deste território, o qual, por seu turno, é bastante específico, de conhecimento dos sujeitos e ao qual estes se sentem ligados: o tekoha guasu. Portanto, é fundamental se ter em mente que estamos lidando com um espaço totalmente mapeado pelos sujeitos, não apenas de modo cognoscitivo, mas também e, sobretudo, em termos experienciais. Há que se levar em conta, a rigor, uma dinâmica, ou um processo de construção do território, ao longo do tempo, processo este no qual os indivíduos e famílias guarani tiveram papel ativo e não apenas de observadores. A constituição das reservas, como foi visto, não significou que eles ali permaneceram, como em um gueto, meramente assistindo aos acontecimentos, que desfilavam ante seus olhos. Muito embora com diversos constrangimentos e restrições, a circulação pelo território (para o que há o termo nativo oguata, que significa andar, caminhar, com um sentido próprio de andança) permitiu, ao longo do tempo, a manutenção de determinadas atividades - dentre as quais, a caça, a pesca, a coleta, a realização de rituais. É justamente isto, cabe salientar, o que caracteriza um uso continuado, isto é, uma ocupação histórica deste território.

Sumarizando, pode-se dizer que os deslocamentos feitos refletem uma movimentação bastante característica, diversa da migração, dado que não se efetuam a partir de espaços de origem para outros completamente distantes e desconhecidos dos sujeitos; não é outra a constatação a ser feita se nos remetemos a um exemplo concreto. Em 1978, a Funai tomou a iniciativa de transferir grupos familiares kaiowa originários dos tekoha Rancho Jacaré e Guaimbé - que eram, então, reivindicados -, para a Serra da Bodoquena (território dos Kadiweu), a uma distância de cerca de $800 \mathrm{~km}$ ao norte. $\mathrm{O}$ ímpeto pela recuperação da terra fez o grupo retornar, de início a pé, posteriormente com o órgão indigenista oficial se mobilizando para apoiar no transporte.

Em um outro nível de constatação, pelo que foi aqui exposto, é possível se depreender que, para os Guarani, a comunidade política, e mais especificamente o grupo doméstico, são as unidades sociais cujas lógicas de orientação conformam um eixo fundamental, a partir do qual ganha sentido o uso dos espaços territoriais. Portanto, devem ser o grupo doméstico o objeto central a ser focado, o local onde seus membros estão instalados devendo ser visto como um dos fatores na análise. É por este motivo que defendo que o entendimento sobre a ocupação e utilização desse território - ora diversificado em sua composição física e 
infraestrutural - não deve se apresentar ao observador a priori como fragmentária e estanque em cada um destes espaços/ambientes (ou seja, a aldeia, a cidade e a fazenda). Antes, deve-se observar que as atividades e relações aí desenvolvidas acabam por constituir um leque de possibilidades de obtenção de recursos para os grupos domésticos. De fato, a presença de membros de um determinado grupo doméstico em vários ambientes vem potencializar a capacidade de obtenção de recursos e/ou de acesso a estes. Nesses termos, a diversificação das estratégias dos indivíduos é o que permite escolhas de ocupação e exploração do território de modo diferenciado. $\mathrm{O}$ fato de se optar por morar em uma fazenda, cidade, aldeia, beira de rodovia, depende não apenas da falta de espaço nas reservas ou de conflitos, os quais levariam ao abandono destes espaços "aldeãos". Em grande medida, isto depende também dos recursos que são identificados como significativos e que estão ou não presentes nestes diversos ambientes - os quais podem ser diferencialmente avaliados por grupos domésticos diversos. Ter acesso a condições ecológicas que permitem plantar, obter água, ter acesso ao trabalho e à assistência de saúde, por exemplo, são fatores que, combinados entre si, devem ser necessariamente levados em conta se se pretende entender tanto as escolhas feitas quanto os significados atribuídos pelas pessoas, dada a sua presença em um ambiente específico. Portanto, é nesses termos que entendo que, antes de se falar de "índio de fazenda" ou "de cidade" (ou ainda "de beira de rodovia"), percebendo com isto uma identidade específica - constituída fundamentalmente a partir do local onde se está habitando -, deve-se buscar considerar os referenciais dos próprios sujeitos, naquilo que para eles é significativo e valorizado.

\section{Notas}

${ }^{1}$ Outros fatores relevantes surgidos pelo fato de se estar nas cidades foram postos em destaque e analisados pelos autores de Manchester - como a criação de caixas de socorro mútuo, e a valorização de determinadas manifestações culturais, como a dança kalela, que Mitchell (1956) analisou.

${ }^{2}$ No Brasil, os grupos de língua guarani se distinguem entre os Kaiowa, os Ñandéva e os Mbya, sendo que, no Mato Grosso do Sul, apenas os dois primeiros se fazem presentes, constituindo meu foco aqui. Quando utilizo o termo "guarani", estou me referindo tanto a um quanto a outro grupo.

${ }^{3}$ As ações do SPI tiveram consequências muito concretas e profundas para os índios. Especificamente com relação aos Kaiowa e Nandéva, a leitura de relatórios de funcionários seus nas primeiras décadas do século XX revela um total desconhecimento sobre a forma de vida destes grupos (cf. Monteiro, 2003), o que findava por alimentar uma visão absolutamente etnocêntrica, a qual, por sua vez, gerava uma 
ampla gama de ingerências. A fundamentar esta dinâmica estava um poder tutelar, dotado da pretensão de proteger os grupos nativos e determinar o que lhes seria melhor, tendo-se em vista a relação com a sociedade nacional e o Estado - o " grande cerco de paz", para usar a expressão de Lima (1995).

${ }^{4}$ Durante o governo Vargas efetivou-se a criação de colônias agrícolas, sendo uma delas justamente a "Colônia Agrícola Nacional de Dourados" (CAND), que foi estabelecida, em 1943, em terras de ocupação Guarani. Para mais detalhes, ver Fernandes Silva, op. cit.

${ }^{5}$ Monteiro (op. cit.) reproduz documentos nos quais se vê a disputa progressivamente mais acirrada pelas terras, em que mesmo o tamanho proposto pelo SPI para as reservas (isto é, 3. 600 ha) foi respeitado apenas em duas das oito áreas.

${ }^{6}$ Buscando denominar conceitualmente as formas que os grupos sociais assumem fisicamente ao se estabelecerem no espaço, Mauss (1993) cunhou o conceito de morfologia social, tomando em consideração fatores como o volume e a densidade da população, além do modo como ela se distribui no espaço.

${ }^{7}$ Vide carta de jesuíta anônimo, datada de 1620, em MCA, v. I, 1951, p. 166-168.

${ }^{8}$ Dadas as condições presentes hoje nas T.Is., constata-se que, as famílias, em maior ou menor grau, ao manterem poder econômico e prestígio, conseguem manter também maior número de seus membros presentes em um mesmo espaço, em torno da figura de seu chefe, o tamõi.

${ }^{9}$ Donde se traduziria "lugar onde realizamos nosso modo de ser", como o fizeram Melià e o casal Grünberg (1976).

${ }^{10}$ Afirmar isto não implica dizer que os grupos não dispunham de uma percepção de limites. Antes, o que se quer remarcar aqui é a discussão enfrentada por Bohannan (1967) sobre a concepção fundamentalmente "ocidental" de posse da terra, com sua mensuração e divisão - por meio de processos tecnológicos e matemáticos - em partes com limites precisos: as ditas parcelas. A análise do autor se desenvolvia no contexto africano, o qual colocava em xeque esta concepção, característica dos colonizadores europeus que ali chegavam.

11 "Chicha" é uma palavra quéchua, introduzida provavelmente pela colonização espanhola, já que em guarani utiliza-se "kãgui" para designar a bebida fermentada produzida a partir de milho, batata doce, cana-de-açúcar, bebida esta que está diretamente relacionada a ocasiões de descontração e a festividades.

${ }^{12}$ Deve ser notado que, em suas análises posteriores, o apelo a uma tal distinção foi absolutamente superada por Barth, sendo que noções como transversalidades e fluxos passaram a adquirir a centralidade de sua atenção.

${ }^{13}$ Mura (2006) detém-se mais numa reflexão do processo de constituição das comunidades políticas entre os Kaiowa, indicando como os grupos domésticos se constituem e reconstituem, a partir de cisões e do acesso ao território e seu controle.

${ }^{14}$ No que tange mais especificamente às relações educativas em seio ao te' yi/ ñemoñare, ver Benites, 2003, enquanto para uma análise mais extensa sobre a própria organização deste grupo, ver Mura, 2006.

${ }^{15}$ Os kaiowa e ñandéva constroem suas habitações respondendo fundamentalmente a três funções, ou seja, dormitório/cozinha/depósito, sendo o pátio ao redor das 
construções o lugar onde se passa a maior parte do tempo, em conversas entre os membros da família e as visitas, compartilhando-se o tererê- que é a bebida de erva mate em água fria. Para mais detalhes neste sentido, ver Mura, 2000.

${ }^{16}$ Uma das estratégias do SPI na tarefa de administrar as populações indígenas foi criar uma figura de mediação, isto é, o "capitão" indígena, entendido como único e legítimo representante de uma "aldeia". As consequências para os Guarani foram muito negativas, como se pode ver nos estudos de Brand, Thomaz de Almeida, e Mura, op. cit.

${ }^{17} \mathrm{O}$ espaço ocupado pelo depósito não constitui a totalidade deste terreno, de modo que Aníbal está instalado a algumas centenas de metros do próprio depósito.

${ }^{18}$ Neste sentido, ver Pereira, 1999.

${ }^{19} \mathrm{Na}$ "Introdução" a "Os grupos étnicos e suas fronteiras", Barth sugeria entender o grupo étnico como um tipo organizacional, isto é, como uma forma de organização.

${ }^{20}$ Os estudos mais recentes sobre o tema da migração têm posto em destaque aspectos relevantes, como o de que, ao se deslocar, o sujeito muitas vezes está pondo em prática estratégias que envolvem o seu grupo e lugar de origem, orientado por interesses específicos destas referências primárias. Os trabalhos do argelino A. Sayad constituem importante referencial neste sentido.

\section{Referências}

AZANHA, Gilberto; LADEIRA, Maria Elisa. Verbete sobre os Terena. Enciclopédia Povos Indígenas no Brasil [online], nov, 2004. Disponível em: <http: // www.socioambiental.org/pib / epi/terena/terena.shtm>. Acesso em: 10 jul. 2008. BARBOSA DA SILVA, Alexandra. Mais além da "aldeia": território e redes sociais entre os guarani de Mato Grosso do Sul. Tese (Doutorado em Antropologia) - PPGASMN/UFRJ, Rio de Janeiro, 2007.

BARNES, John A. Redes sociais e processo político. In: FELDMAN-BIANCO, Bela (Org.). Antropologia das sociedades contemporâneas. São Paulo: Global, 1987.

BARTH, T. Fredrik. Models of Social Organization. London: Royal Anthropological Institute, 1966.

. Scale and Network in Urban Western Society. In: BARTH, Fredrik (Ed.).

Scale and Social Organization. Oslo: Universitetsforlaget, 1978.

. Cosmologies in the Making. A Generative Approach to Cultural Variation in Inner New Guinea. Cambridge: Cambridge University Press, 1987.

. Os grupos étnicos e suas fronteiras. In: LASK, Tomke (Org.). O guru, o iniciador e outras variações antropológicas. Rio de Janeiro: Contra Capa Livraria, 2000.

Por um maior naturalismo na conceptualização das sociedades. In: LASK, Tomke (Org.). O guru, o iniciador e outras variações antropológicas. Rio de Janeiro: Contra Capa Livraria, 2000b.

BENITES, Tonico. Mbo'e kuatia ñemoñe'ê ha japo kuatia ñe'ê (Fazendo o papel falar e produzindo sua fala). Monografia (Curso Normal Superior) - UEMS, Dourados, 2003. 
. A escola na ótica dos Ava Kaiowá: impactos e interpretações indígenas. Dissertação (Mestrado em Antropologia) - PPGAS-MN/UFRJ, Rio de Janeiro, 2009.

BOHANNAN, Paul. Africa's land. In: DALTON, George (Org.). Tribal and peasant economies. Readings in economic anthropology. New York: The Natural History Press, 1967.

BRAND, Antônio J. O impacto da perda da terra obre a tradição Kaiowá/Guarani: os difíceis caminhos da palavra.Tese (Doutorado em História) - PUC-RS, Porto Alegre, 1997.

CARDOSO DE OLIVEIRA, Roberto. Urbanização e tribalismo: a integração dos Terena numa sociedade de classe. Rio de Janeiro: Zahar Editores, 1968.

. Do índio ao bugre: o processo de assimilação dos Terêna. Rio de Janeiro: Liv.

F. Alves Editora, 1976.

FERNANDES SILVA, Joana A. Os Kaiowá e a ideologia dos projetos econômicos. Dissertação (Mestrado) - IFCH/UINCAMP, Campinas, 1982.

FERREIRA, Andrey C. Tutela e resistência indígena: Etnografia e História das Relações de Poder entre os Terena e o Estado Brasileiro. Tese (Doutorado em Antropologia) PPGAS-MN/UFRJ, Rio de Janeiro, 2007.

GLUCKMAN, Max. Tribalism in Modern British Central Africa. Cahiers d'études africaines, n. 1, p. 55-70, 1960.

LIMA, Antônio Carlos de S. Um grande cerco de paz: poder tutelar, indianidade e formação de Estado no Brasil. Petrópolis: Vozes, 1995.

MANUSCRITO DA COLEÇÃO DE ANGELIS (MCA). Jesuítase Bandeirantes no Guairá. v. I, Rio de Janeiro: Biblioteca Nacional, Divisão de Obras Raras e Publicações, 1951. MAUSS, Marcel. Essai sur les variations saisonnières des sociétés eskimos. Étude de morphologie sociale. In: PUF, 1993. Sociologieet Anthropologie. 5. ed. Paris: Quadrige/

MAYER, Phillip. Migrancy and the Study of Africans in Towns. American Anthropologist, v. 64, p. 576-592, 1962.

MELIÀ, Bartomeu; GRÜNBERG, Friedl; GRÜNBERG, Georg. Los Pâ̂-Tavyterã: Etnografia guarani del Paraguai contemporaneo. In: Suplemento Antropológico de la Revista del Ateneo Paraguayo, v. XI, n. 1-2, 1976.

MITCHELL, J. Clyde. The Kalela Dance. Aspects of Social Relationships among Urban Africans in Northern Rhodesia. Rhodes-Livingstone Papers, n. 27. Manchester: Manchester University Press, 1956.

MONTEIRO, Maria Elizabeth B. Levantamento histórico sobre os indios Guarani Kaiwá. Museu do Índio/Funai. Coleção Fragmentos da História do Indigenismo, 2, 2003. MONTOYA, Antonio Ruiz de. Conquista espiritual feita pelos religiosos da Companhia de Jesus nas províncias do Paraguai, Paraná, Uruguai e Tape. Porto Alegre: Martins Livreiro Editor, 1985.

MURA, Fabio. Habitações Kaiowa: forma, propriedades técnicas e organização social. Dissertação (Mestrado em Antropologia) - PPGAS-MNA/UFRJ, Rio de Janeiro, 2000. . À procura do "bom viver": território, tradição de conhecimento e ecologia doméstica entre os Kaiowa. Tese (Doutorado em Antropologia Social) - PPGAS- 
MN/UFRJ, Rio de Janeiro, 2006.

PACHECO DE OLIVEIRA, João. Uma etnologia dos 'índios misturados'? Situação colonial, territorialização e fluxos culturais. In: PACHECO DE OLIVEIRA, João (Org.). A viagem da volta: etnicidade, política e reelaboração cultural no Nordeste indígena. 2. ed. Rio de Janeiro: Contra Capa Livraria/LACED, 2004.

PEREIRA, Levi M. Parentesco e organização social Kaiowá. Dissertação (Mestrado em Antropologia) - IFCH/UNICAMP, Campinas, 1999.

SCHADEN, Egon. Aspectos fundamentais da cultura guarani .São Paulo: E.P.U./ EDUSP, 1974.

SUSNIK, Branislava. Etnohistoria de los Guaraníes: época colonial. In: . Los Aborígenes del Paraguay, v. II, Asunción: Museo Etnográfico Andrès Barbero, 1979-80. . Cultura material. In: Los Aborígenes del Paraguay, v. IV, Asunción: Museo Etnográfico Andrès Barbero, 1982.

THOMAZ DE ALMEIDA, Rubem F. Do desenvolvimento comunitário à ação política:o projeto Kaiowa-Ñandeva como experiência antropológica. Rio de Janeiro: Contra Capa Livraria, 2001.

WEBER, Max. Comunidades étnicas e Las comunidades políticas. In: Economia y sociedad. Esbozo de sociologia comprensiva. México: Fondo de Cultura Económica, 1983.

WILK, Richard R.; NETTING, Robert McC. Households: Changing Forms and Functions. In: NETTING, Robert McC.; WILK Richard R.; ARNOLD, Eric J. (Eds). Households. Comparative and historical studies of the domestic group. Berkeley: University of California Press, 1984.

WILK, Richard R. Households in Process: agricultural change and domestic transformation among the Kekchi Maya of Belize. In: NETTING, Robert McC.; WILK Richard R.; ARNOLD, Eric J. (Eds). Households. Comparative and historical studies of the domestic group. Berkeley: University of California Press, 1984.

\section{Documentos consultados}

PIMENTEL BARBOZA, Genesio. Relatório apresentado ao Inspetor do SPI (Antonio Martins Vianna Estigarribia) do Estado de Matto Grosso. Documentação do Museu do Índio/FUNAI. Rio de Janeiro, 1927. (Mf 341 - Fg 1210-1249).

PRADO, Joaquim F. Relatório acompanhado de quadro populacional dos grupos indígenas da IR. 5. Documentação do Museu do Índio/FUNAI. Rio de Janeiro, 1948. (Mf 20 - Plan. 309).

. Relatório encaminhado ao Diretor do SPI (Modesto Donatini Dias da Cruz). Documentação do Museu do Índio/FUNAI. Rio de Janeiro, 1949. (Mf 18 - Plan. 264).

Recebido em 11 de setembro de 2008. Aprovado para publicação em 12 de janeiro de 2008. 